\title{
Difficulties Francophone Learners go through in Ghana: The Case of Ghana Technology University College
}

\author{
Michael Owusu Tabiri (Corresponding author) \\ Ghana Technology University College, Faculty of Informatics, \\ PMB 100, Accra, Ghana \\ Telephone: 233-205435923/24 4984077 E-mail: mtabiri@gtuc.edu.gh \\ Gifty Budu \\ Ghana Technology University College, Faculty of Informatics, \\ PMB 100, Accra, Ghana \\ Telephone: 233-501408370/24 4863756 E-mail: gbudu@gtuc.edu.gh \\ Received: October17, 2016 Accepted: November17, 2016 Published: January 9, 2017 \\ doi:10.5296/ire.v5i1.10570 URL: http://dx.doi.org/10.5296/ire.v5i1.10570
}

\begin{abstract}
This research investigates difficulties that Francophone learners encounter in Anglophone countries.

Francophone learners who pursue further studies in Anglophone countries could face academic, social, economic, religious and political difficulties due to their literary incompetence in English language (L3). Through the method of investigation and answering of questionnaires by learners, it was uncovered and affirmed that the main difficulties Francophone learners encounter in Anglophone countries were academic, social, religious, and political. It was revealed that the learning difficulties of Francophone students transcend the academic setting. Thus in the church, entertainment grounds, market and other places they visit and interact, they face difficulties.
\end{abstract}

The participants of this research comprised thirty (30) level 400 Francophone students at the Ghana Technology University College, Accra.

Finally, the work stresses that, finding a solution to academic difficulties could be a stepping 
stone to solving all other difficulties learners encounter. Thus, in finding a lasting solution to Francophone learners' difficulties, the fulcrum must be seeking solution to academic difficulties.

Keywords: Francophone learners, academic, social, religious, political difficulties, practical teaching/learning

\section{Introduction}

Language is a powerful tool for effective communication. However, communicating effectively in English is a big challenge to some Francophone students, particularly Francophone students of Ghana Technology University College. The challenges Francophone students face in expressing themselves in English often translates into academic difficulties, which in turn have a potentially devastating effect on their respective fields of study. This can serve as an impediment when it comes to writing final projects as learners lack proper literary competence.

The linguistic frustration Francophone students face stems from the syntactic configuration differences between the two languages. For example, French demands agreement between a noun and related articles and adjectives whereas English does not follow such pattern. Thus it is difficult for French speakers to form well-structured and meaningful sentences in English.

1. Les étudiantssont intelligents. (The (male) students are intelligent)

2. Les étudiantes sont intelligentes. (The (female) students are intelligent)

3. Les femmes sont parties.(The women have left)

4. Une fille studieuse et sérieuse. (A studious and serious girl)

The linguistic frustration that Francophone students face caught the attention of the researchers and compelled them to carry out this research. Consequently, in this work, the researchers explored how the aforementioned challenges could be addressed.

The work investigates difficulties that Francophone learners encounter in the Anglophone University setting and the Ghanaian community as a whole. The paper concludes with the proposal of possible solutions to the difficulties identified.

Language is an arbitrary vocal symbol used for human communication (Akpanglo-Nartey, 2000). It becomes a powerful tool then, for effective communication. Applied Linguistics draws multidisciplinary theoretical and empirical perspectives to address real world issues and problems in which language is the central focus (Brumfit, 1997). The acquisition of a Second (L2) or third Language (L3) harnesses different perspectives to address specific issues of how people acquire a second or third language and why some people are unsuccessful in this pursuit.

This research investigated the academic, social, religious and political difficulties Francophone learners experience in an Anglophone University.

The main objective of the study is to find out Francophone learners' difficulties in Anglophone countries. The specific objectives addressed in the study were; how to help 
Francophone learners in Anglophone countries to overcome their challenges, analyzing academic, social, religious and political difficulties of Francophone learners face in Ghana, methods of enhancing learners' performance in their field of study and finally, how to apply knowledge and skills acquired to real life situations.

In addressing the objectives, research questions pertaining to the difficulties Francophone students face in the Anglophone University environment were discussed. The research questions provided a framework that would help find solutions to the problems Francophone students face. The research questions that guided the study are as follows:

i. How could lecturers examine academic, social, religious and political difficulties of Francophone learners?

ii. What are the specific learning difficulties of Francophone students of Ghana Technology University College?

iii. How could those difficulties be minimized?

iv. How could lecturers assist Francophone learners to acquire language skills?

v. How could lecturers make teaching and learning practical?

The literature review of this research takes its roots from various levels; academic, social, religious and political difficulties. It behooves us to discuss the literature that has some bearing on our work as follows:

"Ours is a...nation ... where in community we enter into the bond of learning together."(Hamilton 1995).Hamilton's assertion implies that learning together is inevitable, communal and corporate affairs. The difficulties touched upon in this work are addressed from different angles; academic, social, religious and political difficulties.

Maduekwe (2007 citing Brown 1989), communicative competence is "the ultimate goal of learners as they struggle with function, discourse, registers and all aspects of human interaction and linguistic negotiation." In the pursuit of a Second (L2) or third (L3) language, the student's ability to competently express him or herself is the ultimate linguistic goal.

According to Tabiri (2016), "In Anglophone countries like Ghana and Nigeria, where all the University courses are taught in English except French courses, Francophone learners who pursue further studies in Anglophone countries definitely go through difficulty in understanding the meaning of English words and sentences."The aforementioned quotation highlights the fact that when placed in an Anglophone tertiary environment, it is inevitable for Francophone learners to face linguistic difficulties.

Similarly, Burke and Wyatt (1996) assert that Francophone learners are likely to face language challenges in an environment where the English Language is the language of communication. In a related development, Pineteh (2014), posits that English Language becomes a challenge for students from countries where the English is not the medium of instruction. This affects their academic performance as they mostly fail to meet academic standards prescribed by the University.Therefore, it is important to build the students' communicative competence in order to overcome these challenges (Park, 2010, Sakyi-Baidoo, 2003). However, some Francophone learners find it difficult to communicate effectively as a 
result of their negative attitude towards learning English language (Soken, 2011).

When the learner shuns negative attitude toward the target language, a myriad of doors of communication and dialogue for understanding are opened and widened for the acquisition and enjoyment of a second (L2) or third language (L3) (Kisseadoo, 2002 p. 2). Taking a cue from Kisseadoo, the way people view themselves in communication affects the quantity and quality of second (L2) or third language (L3) acquisition. The flexibility and enjoyment of the Second or Third Language is tremendously varied across learners in cognitive fashion and within learners in strategic ways.

\section{Methodology}

The study site involved Final Year Francophone students of the Ghana Technology University College, Accra campus. The study population or sample for the study comprised students from Togo, Benin, Côte d'Ivoire, Gabon and Niger who have been in Ghana for more than three years pursuing degree programmes such as Bachelor of Business Administration, Bachelor of Information Technology and Bachelor of Telecom Engineering. This study used semi-structured interviews to gather data. Semi-structured interviews were used as it provides opportunity to gain deeper knowledge from the research participants on difficulties Francophone learners go through (Edwards et al., 2013 and Henn et al., 2006). As all the respondents were final year level 400 students, the researchers were compelled serendipitously to gather some data via Whatsapp Group Discussion, dubbed: Francophone Learners.

Table 1. Final Year Level 400 Francophone Students

\begin{tabular}{llll}
\hline LEVEL 400 FRANCOPHONE LEARNERS(GENDER) & MALE & FEMALE & TOTAL \\
\hline NUMBER OF LEARNERS & 18 & 12 & 30 \\
\hline
\end{tabular}

\section{Results and Research Implications}

\subsection{Academic Difficulties Francophone Students Encounter}

All issues relating to educational system, scholarly and intellectual problems of learners are termed in this work as academic difficulties.In the University, the course outline with the stated objectives, aims and references are exposed to the students to read extensively to facilitate learning. The International Literacy Association reiterates on the need to be able to read, write, and communicate effectively as this connects people and empowers them to achieve things they never thought possible. However, some Francophone students find it difficult to comprehend what they read at this level. This supports the assertions that "readers' linguistic knowledge may influence their ability to read with understanding" (Tsadidey, 1993; Boateng, 2004). The reason is that their linguistics knowledge in English language is limited. This makes them fail to make sense of print, translating the black marks on the page to meaning. The construction of meaning involves the reader connecting information from the written message with previous knowledge to arrive at meaning - at an understanding (Day \& Bamford, 1998, p.12). That is reading from the cognitive point of view. This is evident in the 
feedbacks they give in class exercises and assignments as they are unable to bring to bear their knowledge of the English Language. It is a measure and a reflection of the students' English language acquisition in relation to their academic level. This creates confusion for them as they struggle to make meaning in context. To avoid this kind of confusion, (Yule 1996; Celce - Murcia and Larsen- Freeman 1999) emphasise that "A better way of looking at Linguistics forms in different languages would be to use this notion of 'elements' in the message, rather than to depend on identifying 'words'." The learners should understand the key elements or the content words which carry most of the meanings in the sentences rather than to rely on the functional words. This speeds up comprehension as the central message can be grasped when content words are left in than when only functional words remain.

Some students share their experiences of academic difficulties in an interview with the researchers. They complain that sometimes vocabulary, expressions and structures in context are obstacles in understanding concepts. This affects their academic performance to a great extent because there are instances where they carry valuable ideas which are inspirational and may be likened by others, but the degree of explanation may not sound meaningful and convincing to be accepted. In an attempt of improving their English language skills, they seek further attention and explanation from lecturers and colleagues for improvement, but sometimes they are not pleased with performance and results despite their efforts.

The majority of the students had problems with all the four language skills-listening, speaking, reading and writing. Without altering the grammatical errors of the learners, we were able to find out their academic difficulties through some selective original responses they gave as follows:

\section{I find it difficult to understand when the teacher is teaching}

2. I some don't know the words I should use when discussing in English

3. I find the lecture notes difficult to read and understand

4. I always commit some errors particularly when writing English language.

5. The major problem I had was comprehension, even though I went to a language school for 7 months.

6. The reason is what they teach there had practically nothing to do with my field of study (IT) in GTUC.

7. The lecturers taught the whole class without considering whether Francophones might have difficulties.

8. This situation had me to make frequent use of a dictionary and do more research which of course I am glad I did because it greatly helped me.

9. A technology school that teaches more theory instead of providing practical classes.

10. And with all that they expect students to elaborate outstanding projects that require practical knowledge.

11. Much practical work is needed.

12. My academic difficulties face me as a student of GTUC is presentation

13. As for me, I'm shine person and I'm afraid because some of friend watch me and my colleague too, and when we do mistake, there are stating laughing about you, and writing the essay as for francophone writing in English is not easy. 


\subsection{Social Difficulties}

All issues and difficulties that learners encounter as a result of interaction of people in the society or community are termed as social difficulties. Quan-Haase (2016), posits that "There is no doubt that we have witnessed an unprecedented proliferation of social media tools, such as Twitter, Facebook, Tumblr and Pinterest where people present themselves of connecting with friends and family, and of keeping up with the news and with the world events, work and everyday life." If the information posted on these fora are in English language, it would block the Francophone students of getting every detail of the information.

Besides, we find ourselves in an era of technological pervasiveness and networking, where socialization is vital to development. This makes the Francophone students unable to socialize completely because of the language barriers. Thus, limited vocabulary and expressions do not make them comprehend information to express their views clearly. There are instances when you communicate to them, they tell you to explain further to the level they understand. Meanwhile, the sentence construction may be in the simplest form. The effect is that they turn to socialize more with their Francophone counterparts and communicate in French instead of the English. This attitude does not make them bridge the gap in an attempt to acquire the second language which is needed for communication and transaction purposes in Ghana. Have you ever thought of their feelings and attitudes during social gatherings where English speakers dominate? And again in the communities they live? At the market places? A student asserts that sometimes the sellers she buys from the market are neither English speakers nor French speakers and this makes transactions difficult. The seller speaks only the local languages which she does not understand for a smooth business transaction. In order to be comfortable, she goes there in a company of his Ghanaian friends who stand in to transact business on her behalf because of their fluency in the English and the local languages. This sometimes places financial inconveniences on her as she pays for their fares. On other occasions, the time her friends may agree to accompany her to the market may not suit her, but she has to agree to avoid being cheated. They are unable to cultivate a friendly relationship with the traders because of language barriers. Do you know that speaking a common language with your communicators has its own advantages and disadvantages? That is why some Francophone learners have the perception that they are cheated when transacting business, though the assertion may not be true.The type of questions used and results retrieved are as follows:

As a Francophone student in Ghana, what are the difficulties you go through as you try to socialize; interacting with people; at a social gathering, living in your community, at the hall of residence, at the hostels, at the market; buying and selling of goods?

\section{At a social gathering}

1.) At a social gathering I attended few months after my arrival in Ghana, some of the guest where acting weird towards me.

2.) Some were just starring at me to the point that I had to approach them. Probably it is because they have noticed that I am a foreigner.

3. It was difficult some of ghaneene there are not close with French because our culture and 
the living.

\section{In the community}

1) Unlike at social gathering, it is quite easy to socialize.

2) In my case, neighbors approached me, asking me to teach them French, and also classmates.

3) It is also thanks to them that I was able to open myself to their culture and got to express myself in English without fear.

4) These not make it as friend because of the standing how there are living francophone like spend money than Ghaneen.

\section{At the market}

1. I have realized that if one wants to buy something or ask for a service for example, it is best if he/she speaks the common local tongue (Twi).

2. Luckily, those leaving in the country for some time and who are willing to learn some words and expressions have it as a advantage.

3. But the new comers always have to struggle first of all with the English, and if the seller does not understand and/or does not speak English and also if the seller is not in a good mood, he/she can become verbally aggressive. It is discouraging and has one compelled to buy something he/she did not intend to.

The price is not the same as francophone, there double the price and there speaking twi, this language the francophone they don't understand

\subsection{Religious Difficulties}

All problems that learners go through that impede smooth transmission of their belief or that has a bearing on religion are considered as religious difficulties.Religion is "an organized system of beliefs, ceremonies, and rules used to worship God or group of gods." A person becomes committed to his religious faith and observes the principles as such. He builds a personal attitude based on his faith and scrupulously conforms to the rules and regulations attached to his religion.

The University finds on its campus quite a number of religious denominations where the students meet and worship based on personal faith and attachment. Others also prefer to step out of campus to worship at the various churches and worship centres. Sermons are mostly preached in English and translated to the various local languages for the congregation to comprehend and adhere to the teachings. The Francophone learners do not fully understand the sermons since the language which the Minister's message is preached is sometimes a barrier. This is very crucial because the message is released to the congregation with the intent of transforming lives, winning souls to Christ and expanding the Kingdom of God. The sermon becomes meaningless to those who fail to understand and conform to the principles governing the message or content. Language barrier or difficulty in understanding, therefore, contributes significantly to soul robbing and depriving people of the greatest advantages and conveniences that religion brings to man. A few churches do interpret the sermon to French to 
benefit the Francophone learners.

As a Christian, Moslem, what are the difficulties you face as you go to church/ mosque?

1. As a Christian, precisely Catholic, I did not have problems when it came to prayer and understanding the celebration for I know how it happens.

2. The main problem I had and I still have is the distinction that is exercise even in places like church.

3. Forcing people to seat at a specific place and mostly the fact that Auctions are being held there too. Making me wonder if the content of their Holly Book is different from mine. Because in Jerusalem, Jesus scattered people merchandise for they settled and were selling in the Temple court.

For that we don't have difficulty for that, they don't bad behavior.

\subsection{Political Difficulties}

He who says he does not do politics really does so. All the issues that do not permit learners to benefit from political system or that serve as a pullback to all that concerned party politics are termed as political difficulties. The University promotes various programmes of study by welcoming international students through the rich and lucrative programmes. Some Francophone learners have the capacity to occupy certain offices on campus during students' politics. But many people do not file for these positions because of the difficulties they encounter in understanding political jargons in English. Activities that relate to influencing the actions and policies of government or getting and keeping power in a government are crucial. Therefore, it should be explicitly stated for clear decisions to be taken by interested parties. In an environment where they act as observers, they should not be denied of the message.Every clique has its language. Politicians have a language of their own which often appears in English in the media reports. How do they demystify the political language, if the language the politicians use hampers their understanding with respect to the topic being discussed? Until they expose themselves to be familiar with these terms, they will definitely not enjoy Anglophone politics particularly during electioneering period.

What are some of the challenges you face as a Francophone student as you try to learn or know about the Politics of Ghana?

1. As I was getting to know the country as a whole entity, I have got to understand that culture is very dear to Ghanaians. And I get to adapt to it even though I am not happy about how things are handled (light issue for example).

2. Sometime is the word there are using it difficult to understand the sentence.

\subsection{Any Other Comments (Optional)}

1. The major difficulty foreigners students face always is about obtaining the necessary it legalized documents (resident permit and non citizencard) for his / her stay in the country. We do not even know the importance much less the use of the non citizen card but they oblige us to have it. They lied to us that we can use it at the banks, borders, and as a valid identification card but everywhere you show the card you are told to 
put it away and give a passport rather. We came here to study and it is in you benefits. Instead we are being treated like a bag money that can be manipulated anyhow to bring the cash out of it. It is unfair.

2. I suggest that the school have to organize small session for francophone, for explanation course may after or when the lecturer teactching in class.

We would like to emphasize that the above responses or findings (italicized) were not altered in terms of construction of sentences and presentation of ideas in order to enable readers to appreciate and assess the real Francophone learners' difficulties.

From the foregoing analysis, one can see that the smartest mode of acquiring a second or third language runs beyond the classroom or academic setting. In a classic period of analysis comparability criterion involved other relations such as the English Language usage in different settings in the context of socialization - community, market, religious setting and in the political arena. The dimensions give the chance to fill the gaps and give new impact to the development of teaching and learning a language in a flexible manner

\section{Recommendation and Contribution to Knowledge}

To begin with, to find a lasting solution to learners' academic difficulties, it would be highly expedient to establish language centres as Ghana Technology University College has started, at the various universities to inculcate in Francophone learners acquisition of language skills before admitting them to pursue university programmes in Anglophone countries. In other words, it would be highly crucial to incorporate Applied Linguistics-cum-English Proficiency (ALEP) courses at the various Language centres in order to lay a solid foundation in the language that should have some bearing on programmes that Francophone learners pursue in tertiary institutions.

Also, Language Acquisition Mentorship (LAM) must be vigorously encouraged in Anglophone universities to facilitate language learning among Francophone learners. In other words, faculty members in Anglophone countries must do well to mentor Francophone students who pursue various degree programmes in their universities to enable them to learn English language naturally and effortlessly every day. In the same way, the Francophone learners should also rise to embrace the language as they build rapport and familiarize themselves with Anglophone students.

There should be English language learning continuity (ELLC). This we mean, the English language should be a subject of study throughout the four year programme for all Francophone students who pursue further studies in Anglophone institutions. Unlike instances where students read the English at the first year and later drop it to replace subjects that are not English except in the case of students who enrolled in English as a course.

Francophone learners are urged to choose books that are short, appealing, enjoyable, varied and easy to read (Nutall, 2000).

Moreover, formation of Francophone Students Associations particularly English Clubs can be introduced into Anglophone countries with the aim of identifying all students difficulties and 
help them overcome accordingly.

Furthermore, more pragmatic and concrete explanation techniques must be adopted when teaching Francophone students (Tabiri, 2016) and phase out purely lecture or lecturercenteredness education so as to make teaching and learning enjoyable, practical and comprehensive for learners.

To solve religious difficulties, technology can be judiciously used to develop some software capable of translating sermons simultaneously during sermon delivery.

It would be equally important to make the language of political debates simple and self-explanatory in order to enable Francophone students to comprehend and contribute meaningfully to political discussions in Ghana.

To have a well balanced all round development of students, other aspects such as social, religious and political development could not be relegated to the background, and it is for that reason this paper investigated social, religious and political difficulties of Francophone learners as well.

In finding a lasting solution to Francophone learners' difficulties, the fulcrum must be seeking solution to academic difficulties. Once academic difficulties are professionally tackled, social, religious and political difficulties will automatically be solved effortlessly. In other words, the solution to academic difficulties will be a stepping stone to solving all other difficulties learners face. All round solutions to Francophone students' could be represented as follows:

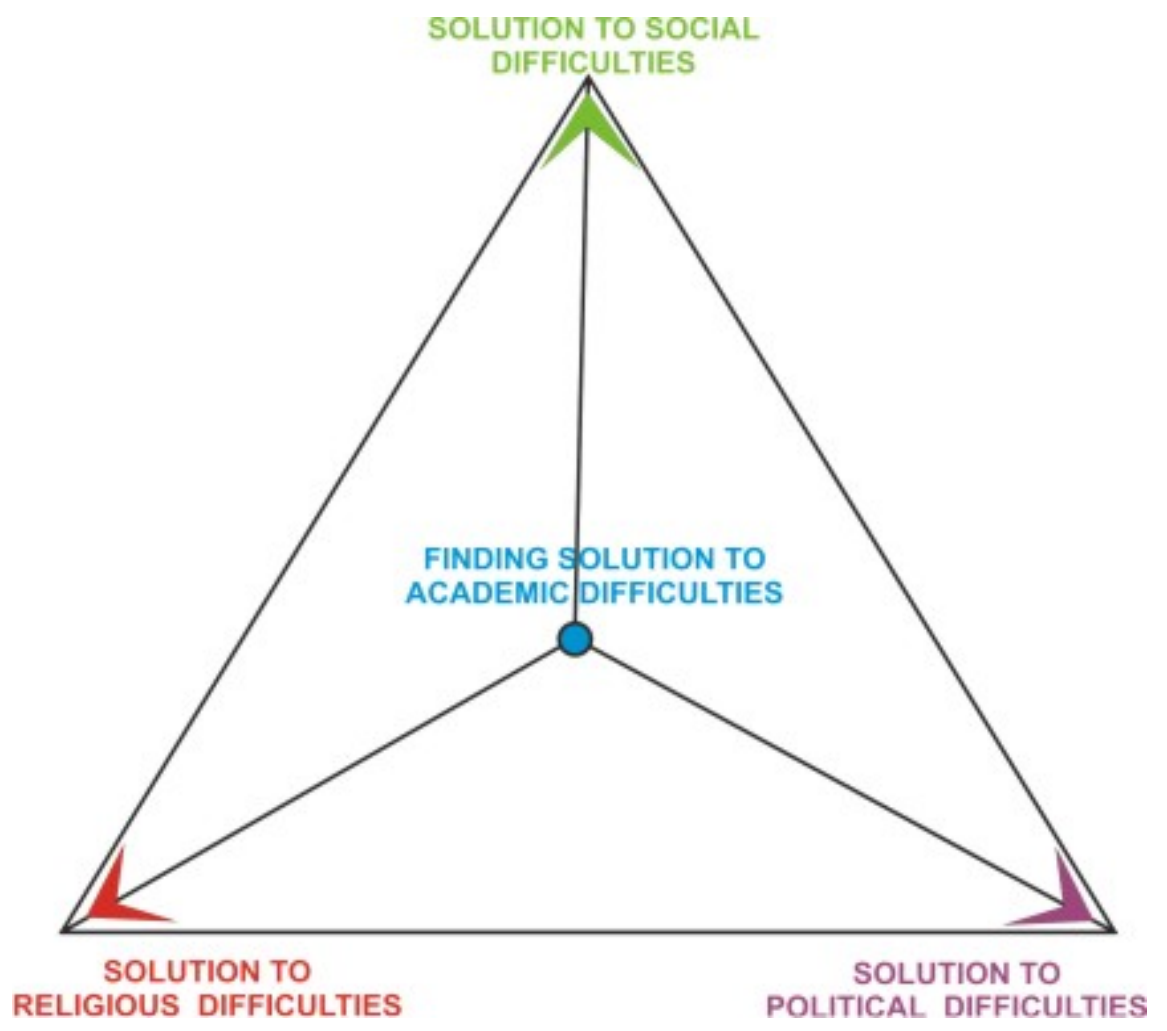

Diagram 1. Finding solution to francophone learners' difficulties 
The Second Language (L2) or third language (L3) can be acquired in a variety of ways such as in a formal and non formal setting. As the Francophone learners' difficulties are identified and addressed academically, it is again addressed in a social, religious and political context to curb the difficulties.

\section{Conclusion}

This paper investigated academic, social, religious and political difficulties Francophone learners encounter in Anglophone countries and tertiary institutions. Thus through the method of investigation and answering of questionnaires by learners, it was uncovered that the main difficulties learners encounter in Anglophone country were academic, social, religious, and political. The work emphasized that once academic difficulties are professionally tackled, social, religious and political difficulties could automatically be solved effortlessly as the solution to academic difficulties could serve as a stepping stone to solving all other difficulties learners face.

In conclusion, to provide learners with the skills of understanding and addressing issues in a broader context and real life situation, education must be pragmatic, practical, proactive and self-explanatory.

\section{Acknowledgements}

The researchers are very thankful and grateful to all level 400 Francophone students (2015/2016) particularly Amorine at the Ghana Technology University for their collaboration and willingness to answer the questionnaires that contributed immensely to the successful completion of the work.

We are also grateful to Professor Nana Osei Darkwa III, the President of the Ghana Technology University college, Dr. Ezer Osei Yeboah-Boateng, the Dean, Faculty of Informatics at the Ghana Technology University College and Dr. Kofi Bobi Barimah, the Director of Research Services and Innovation, Ghana Technology University College for their support and encouragement.

God bless you all to continue to be a blessing in the name of Jesus Christ.

\section{References}

Boateng, M. A. (2004). Teaching English at the Basic Education Level: A PracticalGuide for Teaching. Kumasi: UGC Publishing House Ltd.

Celce-Murcia, M., \& Larsen- Freeman, D. (1999). The Grammar Book: An ESL/EFL: Teacher's Course(2nded.). USA: Heinle \& Heinle Publishers.

Day, R. R., \& Bamford, J. (1998). Extensive Reading in the Second Language Classroom. Cambridge: Cambridge University Press.

Edwards, R., \& Holland, J. (2013). What is qualitative interviewing? (pp. 2-3). Bloomsbury Academic.

Hamilton, V. (1995). Harcourt Horizons-People and Communities. Harcourt, Inc., Page 11. 


\section{Macrothink}

International Research in Education

ISSN 2327-5499

2017, Vol. 5, No. 1

Henn, M., Weinstein, M., \& Foard, N. (2006). A Short Introduction to Social Research. Sage Publication.

Kisseadoo, S. (2002).Conflict Resolution \& Agreement. P. 2. Accra: Asempa Publishers.

Maduekwe, A. N. (2007). Principles and Practice of Teaching English as a Second Language. Lagos: Vitamin Educational Books.

Nutall, C. (2000). Teaching Reading Skills in a Foreign Language. Oxford: Macmillan.

Pineteh, E. A. (2012). Using Virtual Interactions to Enhance the Teaching of Communication Skills to Information Technology Students. British Journal of Educational Technology, 3(1), $1-18$.

Quan-Haase, A. (2016). Technology \& Society: Social Networks, Power \& Inequality. p. ix. Ontario: Oxford University Press.

Sekyi-Baidoo, Y. (2003). Learning and Communicating (2nd ed.). Accra: Infinity Graphics Ltd

Sokeng, P. (2011). The English Language Proficiency of Secondary School. Leavers. Yaounde: Unpublished.

Tabiri, M. O. (2016). Teaching Francophone learners English Vocabulary without Resorting to the Use of L1 and L2, International Conference on Teaching and Learning English as an Additional Language, GlobELT 2016, Antalya, Turkey, Published by Procedia-Social and Behavioral Sciences, Elsevier Ltd, Science Direct, Vol/Issue 232, pp 591-599.

Tsadidey, S. W. K. (1993). A Comprehensive Guide to English Methods for Teachers in Training. Accra: Shepherd Printing Press.

Yule, G. (1996). The Study of Language (2nd ed.). Cambridge: Cambridge University Press. 
Appendix 1: Survey Questionnaire for Francophone Learners

GHANA TECHNOLOGY UNIVERSITY COLLEGE

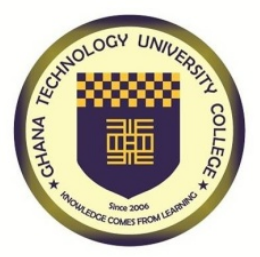

FACULTY OF INFORMATICS

QUESTIONNAIRE FOR FRANCOPHONE STUDENTS

TOPIC: DIFFICULTIES FRANCOPHONE LEARNERS GO THROUGH IN GHANA: THE CASE OF GHANA TECHNOLOGY UNIVERSITY.

Dear student,

This is a research work we are undertakingto help Francophone students to overcome their difficulties in Ghana and enjoy their stay. You are kindly requested to freely tell us your views on the matter.

Please note that the information given us will be treated confidentially.

A. Academic Difficulties.

What are the academic difficulties you face as a student of GTUC?

\section{B. Social Difficulties}

As a Francophone student in Ghana, what are the difficulties you face as you try to socialize; interacting with people; at a social gathering, living in your community, at the hall of residence, at the hostel, at the market; buying and selling of goods?

1. At a social gathering

2. In the community

3. At the market

\section{c. Religious Difficulties}

As a Christian, Moslem or Traditionalist, what are the difficulties you face as you attend church, mosque or the fetish priest?

\section{Political Difficulties}




\section{Macrothink}

International Research in Education

ISSN 2327-5499

2017, Vol. 5, No. 1

What are some of the challenges you face as a Francophone student as you try to learn or know the Politics of Ghana?

Any other comments (Optional)

\section{Thank you.}

\section{Copyright Disclaimer}

Copyright reserved by the authors.

This article is an open-access article distributed under the terms and conditions of the CreativeCommons Attribution license (http://creativecommons.org/licenses/by/3.0/). 